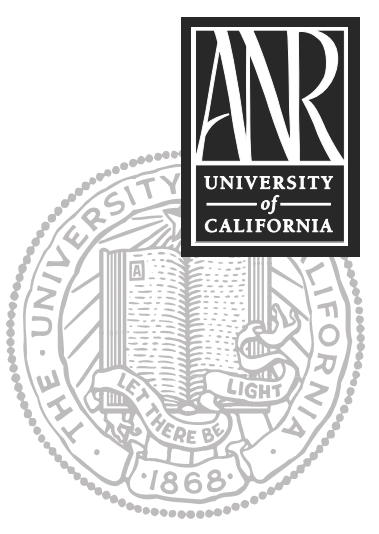

UNIVERSITY OF CALIFORNIA

Division of Agriculture and Natural Resources http://anrcatalog.ucdavis.edu

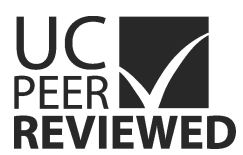

\title{
Ascochyta Blight of Garbanzos
}

CAROL A. FRATE, University of California Cooperative Extension Farm Advisor, Tulare County; SHANNON C. MUELLER, University of California Cooperative Extension Farm Advisor, Fresno County; and STEVE R. TEMPLE, UC Cooperative Extension Specialist, University of California, Davis

\section{INTRODUCTION}

Ascochyta blight, caused by the fungus Ascochyta rabiei, is a serious disease of garbanzo beans (chickpeas, Cicer arietinum L.). There are no other known crop or weed hosts. Ascochyta blight is one of three major disease problems affecting garbanzos in the Central Valley of California. The others are Sclerotinia stem rot (white mold) and a complex of viruses.

\section{SYMPTOMS}

Early symptoms appear on leaves and stems during or after cool, rainy weather. At that point they are tan-colored spots with no border. As the tan spots and lesions continue to develop, small black raised dots, which are fruiting bodies called pycnidia, form in concentric rings within the lesion (fig. 1). Stem lesions tend to become dark brown, the stem is weakened, and it often breaks at that site (fig. 2). If pods are present, they can become infected and lesions with concentric circles appear as the disease progresses (fig. 3). During this phase, developing beans can become infected and, if used for seed, can lead to early infections in the next crop.

\section{DISEASE CYCLE}

Sources of infection in a new crop include infected seed or spores spread from either diseased volunteer garbanzo plants or residue from the previous crop. Infection requires moisture and cool to moderate temperatures $\left(50-75^{\circ} \mathrm{F}\right)$. It is known that the necessary mating types to produce sexual spores are present in California, but sexual fruiting bodies have not been found to date. The asexual spores are spread primarily by splashing water and they move relatively short distances. Spores germinate, enter the plant, and continue spreading through plant tissues, resulting in leaf spots

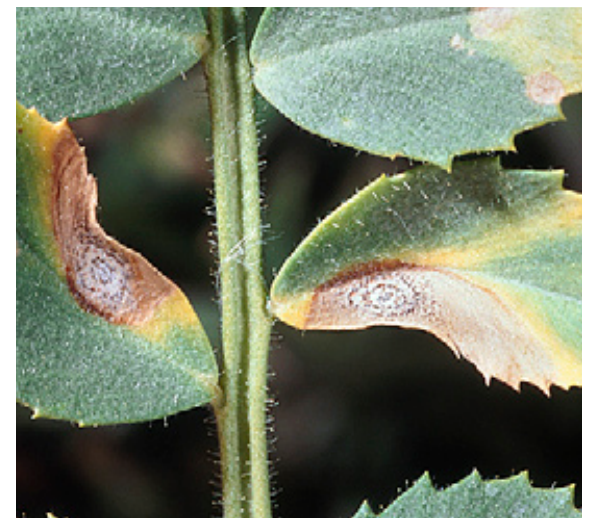

Figure 1. Leaf lesions caused by Ascochyta rabiei showing concentric rings of pycnidia.

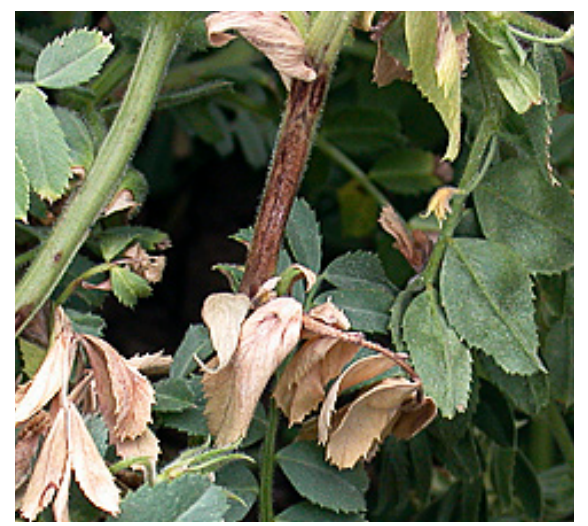

Figure 2. Ascochyta blight stem lesion.

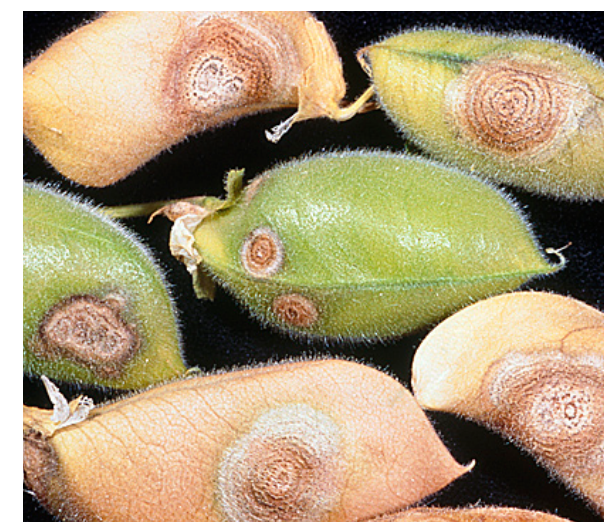

Figure 3. Lesions on pods of garbanzo with concentric rings of pycnidia. 


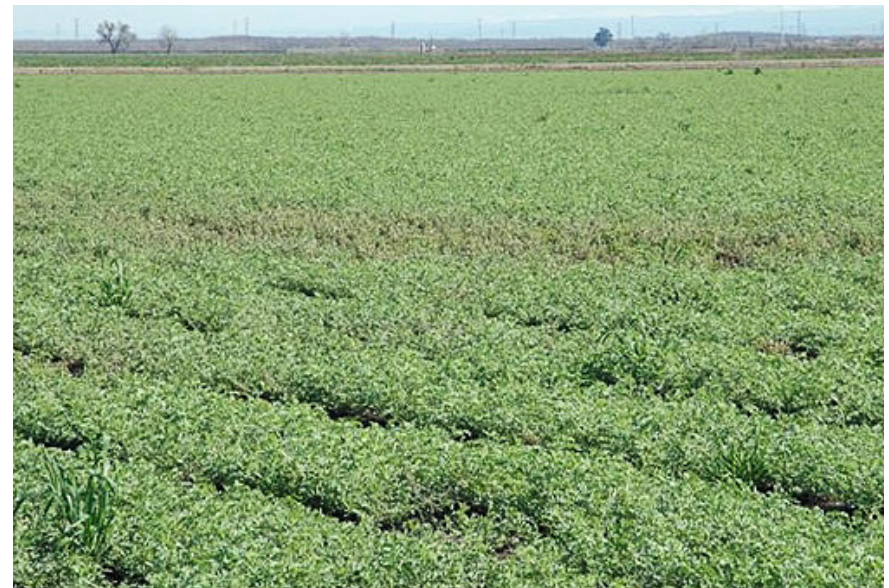

Figure 4A. View of garbanzo field affected by Ascochyta blight.

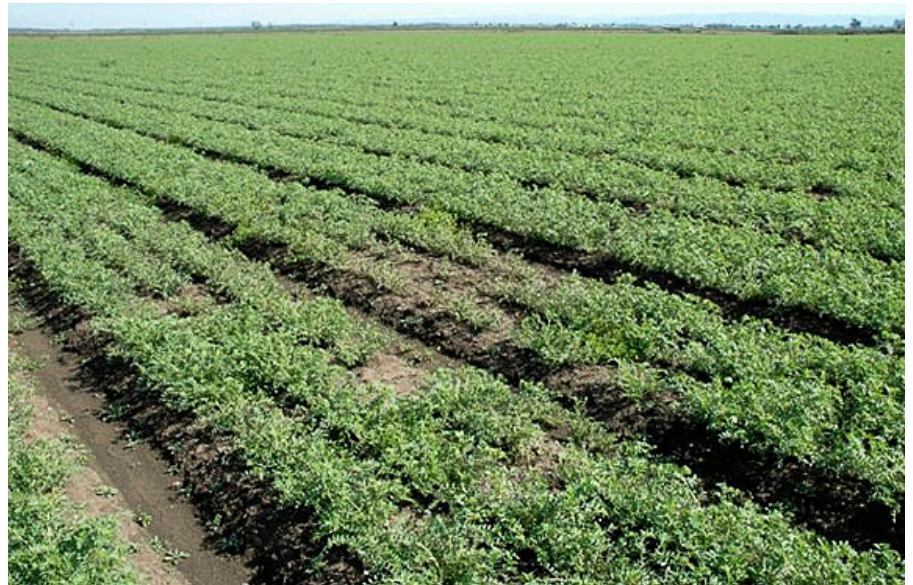

Figure 4B. Close-up view of stand loss associated with Ascochyta blight in garbanzos.

and stem or pod lesions. As the fungus further develops, pycnidia, formed in lesions, produce spores that can spread the disease within the field when environmental conditions are favorable (fig. 4).

\section{DISEASE MANAGEMENT}

Following harvest, incorporate plant residue and destroy volunteer seedlings to reduce the spread of disease. For the new crop, choose a field that has not been planted to garbanzos for at least the previous two years and, if possible, avoid planting in fields adjacent to previous garbanzo fields. Rotation, residue incorporation, and elimination of volunteers are all particularly important when disease levels were high in the previous garbanzo crop.

There are differences among varieties in tolerance to this disease. If disease is expected, it is advisable to plant varieties that are less susceptible to Ascochyta blight. UC Cooperative Extension researchers and local warehouse personnel should be able to help with variety selection. Always plant seed that has been treated with an appropriate fungicide, such as Mertect, to reduce introduction of the fungus by seed.

Monitor fields closely for early symptoms of disease. Avoid sprinkler irrigation, which promotes the spread of disease by splashing spores from infection sites to nearby plants. Once present, the decision of when to apply fungicides depends on variety susceptibility, weather forecasts, and stage of crop development. To avoid development of resistance, it is important to rotate between fungicide chemistries (table 1).

Table 1. Fungicides registered for control of Ascochyta blight of garbanzos in California as of September 2006

\begin{tabular}{|l|l|l|l|}
\hline Trade name & Chemical name & Fungicide group & Manufacturer \\
\hline $\begin{array}{l}\text { Mertect (seed } \\
\text { treatment) }\end{array}$ & thiabendazole & benzimidazole (1) & Syngenta \\
\hline Bravo Weather Stik & chlorothalonil & chlorinated benzonitrile (M) & Syngenta \\
\hline Headline & pyraclostrobin & strobilurin (11) & BASF \\
\hline Quadris & azoxystrobin & strobilurin (11) & Syngenta \\
\hline Endura & boscalid & analid (7) & BASF \\
\hline
\end{tabular}

Bravo Weather Stik is a protectant and should be applied at the first sign of disease prior to rain or sprinkler irrigation. Thorough coverage of the plant canopy is important. Headline, Quadris, and Endura, which in addition to being protective have some curative action, can be applied prior to rain, or within 36 hours after rain. If repeat applications are necessary, choose a fungicide from a different chemistry class to delay the development of resistance by the pathogen. 
PREVENTING THE SPREAD OF ASCOCHYTA BLIGHT OF GARBANZOS

You can help limit the spread of Ascochyta blight by taking the following steps:

- Incorporate plant residue and remove volunteer garbanzo seedlings.

- Do not plant garbanzos back-to-back in the same field; rotation is important.

- Select fields without a recent history of garbanzos (at least 2 years).

- Select varieties less susceptible to Ascochyta blight.

- Plant certified, disease-free seed treated with fungicide(s) approved for Ascochyta control.

- Avoid sprinkler irrigation.

- Monitor fields for disease symptoms early and often during the cropping season.

- When necessary, treat foliage with registered fungicide(s); rotate fungicide chemistries.

\section{FOR MORE INFORMATION}

To order or obtain printed ANR publications and other products, visit the ANR

Communication Services online catalog at http://anrcatalog.ucdavis.edu. You can also place orders by mail, phone, or FAX, or request a printed catalog of our products from:

University of California

Agriculture and Natural Resources

Communication Services

6701 San Pablo Avenue, 2nd Floor

Oakland, California 94608-1239

Telephone: (800) 994-8849 or (510) 642-2431

FAX: (510) 643-5470

E-mail inquiries: danrcs@ucdavis.edu

An electronic version of this publication is available on the ANR Communication Services Web site at http://anrcatalog.ucdavis.edu.

Publication 8259

ISBN-13: 978-1-60107-479-9

(C) 2007 by the Regents of the University of California, Division of Agriculture and Natural Resources. All rights reserved.

To simplify information, trade names of products have been used. No endorsement of named or illustrated products is intended, nor is criticism implied of similar products that are not mentioned or illustrated.

The University of California prohibits discrimination or harassment of any person on the basis of race, color, national origin, religion, sex, gender identity, pregnancy (including childbirth, and medical conditions related to pregnancy or childbirth), physical or mental disability, medical condition (cancer-related or genetic characteristics), ancestry, marital status, age, sexual orientation, citizenship, or status as a covered veteran (covered veterans are special disabled veterans, recently separated veterans, Vietnam era veterans, or any other veterans who served on active duty during a war or in a campaign or expedition for which a campaign badge has been authorized) in any of its programs or activities. University policy is intended to be consistent with the provisions of applicable State and Federal laws. 
Inquiries regarding the University's nondiscrimination policies may be directed to the Affirmative Action/Staff Personnel Services Director, University of California, Agriculture and Natural Resources, 1111 Franklin Street, 6th Floor, Oakland, CA 94607-5201, (510) 987-0096. For a free catalog of other publications, call (800) 994-8849. For help downloading this publication, call (530) 297-4445.

\section{UC PeER REVIEWED}

This publication has been anonymously peer reviewed for technical accuracy by University of California scientists and other qualified professionals. This review process was managed by the ANR Associate Editor for Agronomy and Range Sciences.

To simplify information, trade names of products have been used. No endorsement of named or illustrated products is intended, nor is criticism implied of similar products that are not mentioned or illustrated.

pr-3/07-LR/CM 